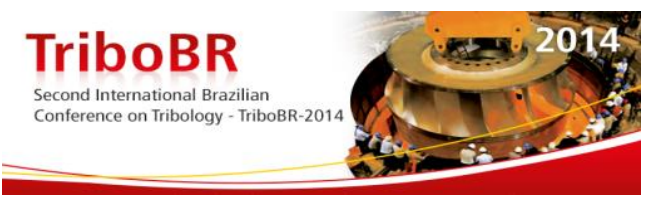

\title{
EFFECT OF SIZE NODULE GRAPHITE ON THE WEAR RESISTANCE OF ADI: A FINITE ELEMENT STUDY*
}

\author{
Luiz Henrique Accorsi Gans ${ }^{1}$ \\ Jairo Alberto Blanco Martinez ${ }^{2}$ \\ Fábio Koda ${ }^{3}$ \\ Wilson Luiz Guesser ${ }^{4}$ \\ Carlos Henrique da Silva ${ }^{5}$
}

\begin{abstract}
First, this works carries an experimental evaluation for austempered ductile iron (ADI) as a gear material. And second, in order to provide a better understanding of the microstructural effect on the stress state of subsurface regions, a finite element method approach was considered using the submodeling tool in ANSYS 11.0. For this, ADI gears were produced from continuous cast iron bars, heat and thermochemical treated and tested in FZG test rig. The results were compared to those of carburized steel AISI 8620 and induction hardened steel AISI 4140 gears. The wear experiments were performed at the temperature of $90^{\circ} \mathrm{C}$ with two torque stages: 135 N.m (running-in) and 302 N.m (steady-state). The time for pitting and spalling on the gears surfaces were measured using image analysis. The results showed a very good potential of using ADI for manufacturing gears, replacing induction hardened steels. Also, the ADI gear with smaller nodules showed higher life for pitting. In contact fatigue tests with severe load, the carburized AISI 8620 steel proved more adequate than the austempered ductile iron, showing that the mechanical properties are critical in the resistance to damage in gear contact. The austempered ductile iron with smaller nodule size showed to be very competitive with wear resistance similar to AISI 4140 steel induction hardened. With ANSYS, it was verified that the nodule size affects the gears life independently of the mechanical properties of the matrix. The results showed that the nodules indicate the presence of a concentration stress, but their size doesn't affect the contact fatigue life as much as the total amount of nodules, regardless of the ductile iron microstructure. The size and number of nodules affects both the nucleation and the propagation stage of cracks. ADls with higher amount of nodules have a greater wear resistance. Also, compared to the Hertz contact theory (isotropic material), the presence of graphite nodules indicates a non-isotropic material and made the maximum shear stress point moves toward the surface.
\end{abstract}

Keywords: Fatigue contact; Austempered ductile iron; Gear; Finite element analysis.

\footnotetext{
Mechanical. Eng., Federal University of Technology - Paraná, Curitiba, Paraná, Brazil. MSc., Federal University of Technology - Paraná, Curitiba, Paraná, Brazil.

MSc., Federal University of Technology - Paraná, Curitiba, Paraná, Brazil.

Dr. Eng., Universidade do Estado de Santa Catarina (UDESC) and TUPY S.A., Joinville, Santa Catarina, Brazil.

5 Dr. Eng., Federal University of Technology - Paraná, Curitiba, Paraná, Brazil.
}

\footnotetext{
* Technical contribution to the $2^{\text {nd }}$ International Brazilian Conference on Tribology - TriboBR 2014, November $3^{\text {rd }}$ to $5^{\text {th }}$, 2014, Foz do Iguaçu, PR, Brazil.
} 


\section{INTRODUCTION}

The mechanical properties presented by austempered ductile irons (ADI) have motivated many engineering teams to develop new applications for this material, specially combining values of strength and ductility [1].

The main application of austempered ductile irons occurs in situations involving abrasive wear. Typical examples are pieces of earthmoving equipment and mining. In the automotive industry, the use of ADI focuses mainly on parts subjected to high mechanical stresses associated with impact requests, such as suspension parts for vehicles [2]. In this case, one option is to select the ADI grades 1 and 2 according to ASTM-06 A897M.

Flat washer tests were carried out by Dommarco [3], with austempered ductile irons, ductile iron quenched and tempered and AISI 4140 steel quenched and tempered. The results of this work have shown that nodular cast iron can have better fatigue resistance than AISI 4140 steel if the nodules size is small (mean nodule diameter around $15 \mu \mathrm{m}$ ). These authors also observed the effect of contact pressure, varying the sphere diameter of the test, and they suggest that the "contact area / area of the graphite nodule" ratio is correlated with the contact fatigue resistance.

Whereas the fatigue phenomenon is the ultimate responsible for the most of the damage in gears, crack nucleation and propagation periods are directly related to the total number of life cycles in these components. The graphite nodules act as stress concentrators and they are responsible for the cracks nucleation. Both size and shape of nodules accelerate the propagation of these cracks. Greno [4] showed that the ability of crack propagation depends on the amount and size of the nodules. In ADls with higher number of nodules it is lower the capacity of branch on the tips of cracks.

The ADIs also exhibit fracture toughness in the order of 50 to $85\left[\mathrm{MPa} . \mathrm{m}^{1 / 2}\right]$, which are very similar to alloy steels, such as AISI 4140 heat-treated. ADIs fracture toughness is strongly influenced by graphite aspects: average nodule diameter, average distance between graphite nodules, nodularity and number of nodules per unit area. The ductile fracture process in ADls engenders nucleation of voids at graphite nodules, their growth and their coalescence. Fewer branching cracks result a greater energy available during the propagation stage [5].

The use of austempered ductile irons in gears has been the subject of several studies [6-8], aiming at the reduction of machining costs and noise in service. But that application is caught up in technical and economic difficulties. In gears under severe loads, for example, the replacement of carburized steel by ADI presents no technical advantages (as shown in the experiments of this work). Moreover, in the sand casting process, the manufacture of gears is not economically feasible, given the geometric simplicity of casting part that will result in the gear (machined).

The present work focuses on the use of austempered ductile irons in gears. Here it's presented a new alternative for the production of gears from nodular cast iron bars obtained by continuous casting. It's suggested to use gears in medium severity, usually produced in steels submitted to surface hardening.

\footnotetext{
* Technical contribution to the $2^{\text {nd }}$ International Brazilian Conference on Tribology - TriboBR 2014, November $3^{\text {rd }}$ to $5^{\text {th }}$, 2014, Foz do lguaçu, PR, Brazil.
} 


\section{MATERIALS AND METHODS}

\subsection{Materials}

In this paper, the materials and treatments used to manufacture the spur gears are shown in Table 1.

Table 1. Treatment sequence performed on the gear materials

\begin{tabular}{|c|c|c|}
\hline SPUR MATERIAL & \multicolumn{2}{|c|}{ HEAT and THERMOCHEMICAL TREATMENT } \\
\hline \multirow{3}{*}{ AISI 8620} & Carburizing & $\begin{array}{r}\text { Temperature }=880^{\circ} \mathrm{C} \\
\text { Time }=16 \text { hours }\end{array}$ \\
\hline & Quenching & Oil temperature $=130^{\circ} \mathrm{C}$ \\
\hline & Tempering & $\begin{array}{r}\text { Temperature }=200^{\circ} \mathrm{C} \\
\text { Time }=2 \text { hours }\end{array}$ \\
\hline \multirow{2}{*}{ AISI 4140} & \multirow{2}{*}{ Surface Hardening } & Induction hardening \\
\hline & & Induction coil method \\
\hline \multirow{2}{*}{ ADI 1} & Austenitization & $\begin{array}{r}\text { Temperature }=890^{\circ} \mathrm{C} \\
\text { Time }=2 \text { hours }\end{array}$ \\
\hline & Austempering & $\begin{array}{r}\text { Temperature }=290^{\circ} \mathrm{C} \\
\text { Time }=2 \text { hours }(\text { in salt bath })\end{array}$ \\
\hline \multirow{2}{*}{ ADI 2} & Austenitization & $\begin{array}{r}\text { Temperature }=900^{\circ} \mathrm{C} \\
\text { Time }=2 \text { hours }\end{array}$ \\
\hline & Austempering & $\begin{array}{r}\text { Temperature }=270^{\circ} \mathrm{C} \\
\text { Time }=2 \text { hours }(\text { in salt bath })\end{array}$ \\
\hline
\end{tabular}

The gears were machined and submitted to heat and thermochemical treatment. The ADI materials were supplied by TUPY S.A. in round bars with diameter of $130 \mathrm{~mm}$ and length of $1880 \mathrm{~mm}$. The process of foundry is continuous casting. Table 2 shows the chemical composition of materials. The ADI composition was obtained by spectrometer and combustion chemical analysis and the data for the steels are the expected chemical composition.

Table 2. Chemical composition of ADI and alloy steels

\begin{tabular}{c|c|c|c|c|c|c|c}
\hline Materials & $\mathrm{C}$ & $\mathrm{Mn}$ & $\mathrm{Si}$ & $\mathrm{Cr}$ & $\mathrm{Mo}$ & $\mathrm{Cu}$ & $\mathrm{Mg}$ \\
\hline AISI 4140 & $0.38-0.43$ & $0.75-1.0$ & $0.15-0.35$ & $0.8-1.1$ & $0.15-0.25$ & - & - \\
\hline AISI 8620 & $0.18-0.23$ & $0.70-0.9$ & $0.15-0.35$ & $0.4-0.6$ & $0.15-0.25$ & - & - \\
\hline ADI 1 & 3.1 & 0.2 & 2.3 & 0.03 & 0.3 & 0.7 & 0.04 \\
\hline ADI 2 & 2.8 & 0.4 & 2.4 & 0.02 & - & 0.6 & 0.03 \\
\hline
\end{tabular}

\footnotetext{
* Technical contribution to the $2^{\text {nd }}$ International Brazilian Conference on Tribology - TriboBR 2014, November $3^{\text {rd }}$ to $5^{\text {th }}$, 2014, Foz do Iguaçu, PR, Brazil.
} 


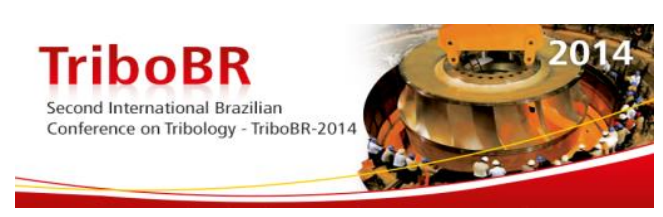

Both ADI alloys present different strategies for temperability achievement, a necessary property for this material. ADI 1 represents the classical approach, where molybdenum (Mo) is added to provide temperability and a low percentage of manganese $(\mathrm{Mn})$ is given to minimize segregations in eutectic cell contours that decrease its tenacity.

In the other hand, ADI 2 was austempered in a lower temperature, which provides a higher cooling rate and requires a lower temperability in this alloy. So, Mo was removed from $A D I 2$. In order to compensate the temperability reduction, the $\mathrm{Mn}$ percentage was increased because its effect on the tenacity is smaller in lower austempering temperatures. Thereat, the inoculation in ADI 2 was also increased, which led to a considerably rise in the graphite number and to a higher segregation distribution. These ADI 2 chemical modifications also imply in a higher elongation. The metallographic sample preparation was carried out by using standard techniques. Metallographic etching was performed employing $2 \%$ Nital. Figure 1 shows the photomicrograph of pinion teeth of all materials after the chemical etching.

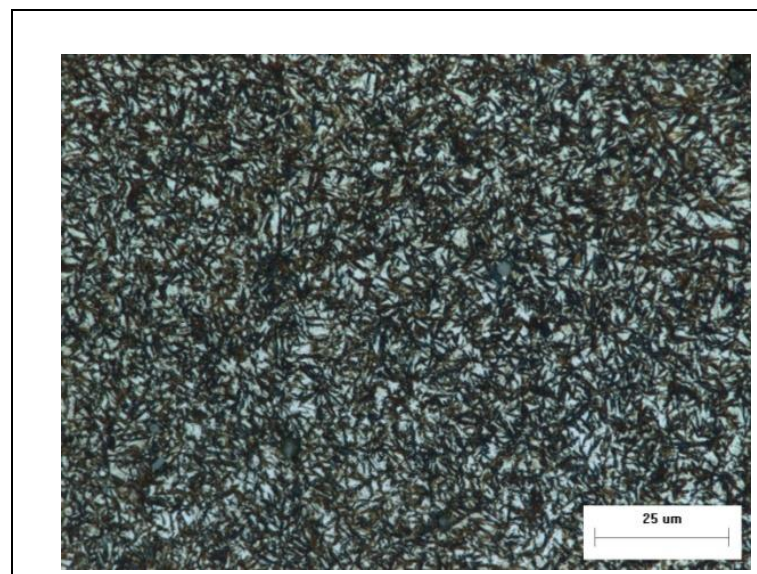

(a)

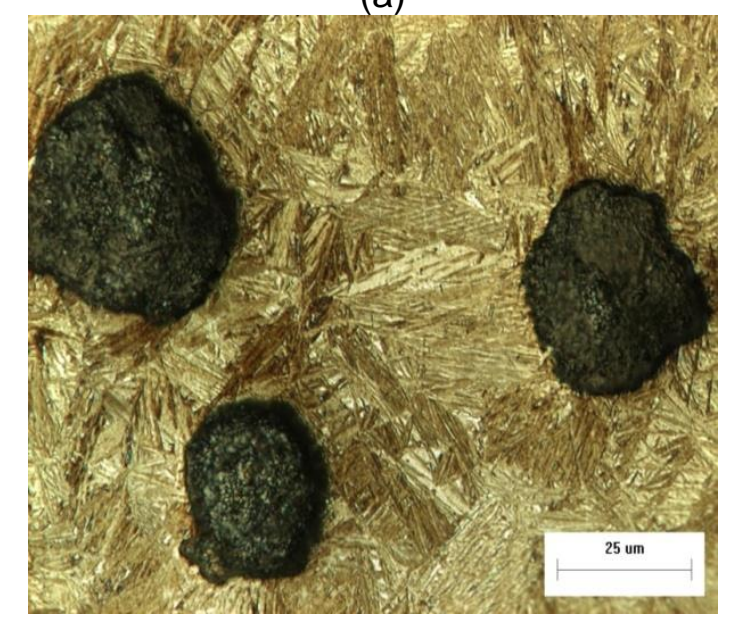

(c)

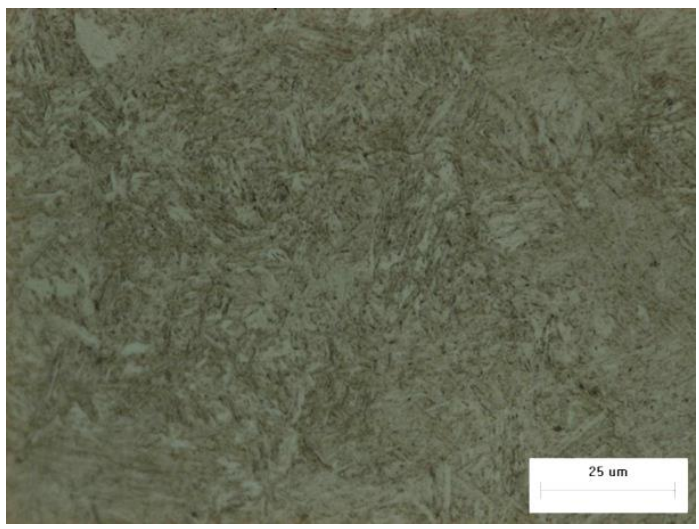

(b)

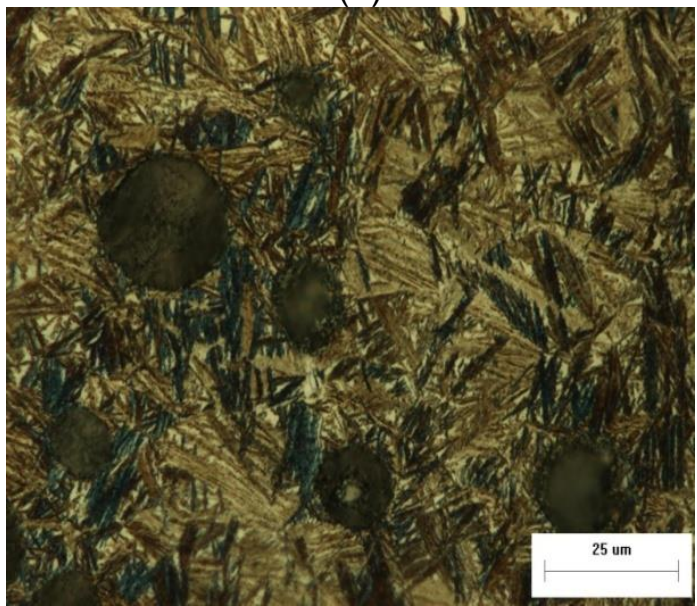

(d)

Figure 1. Pinion photomicrograph: (a) AISI 8620, (b) AISI 4140, (c) ADI 1 and (d) ADI 2.

*Technical contribution to the $2^{\text {nd }}$ International Brazilian Conference on Tribology - TriboBR 2014, November $3^{\text {rd }}$ to $5^{\text {th }}$, 2014, Foz do Iguaçu, PR, Brazil. 


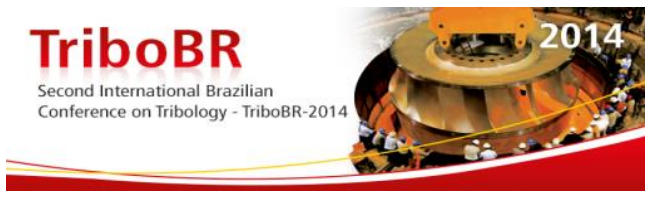

Figure 1 (a) and (b) shows the presence of the martensitic microstructure on the steel gear teeth surfaces. The low chrome percentage in ADIs avoided the solidification carbonates formation, as shown in Figures 1 (c) and (d). Given the lower austempering temperatures and lower diffusivity, it's already expected that the ADI shows low amount of retained austenite due the little carbon segregation during the austempering. Ausferrite needles are smaller in the ADI 2 because its higher nodules number results in smaller austenite grain sizes, which induces an ausferritic microstructure refining and enhances its mechanical properties.

Nodularity and nodule count values were measured by using both the ASTM A 247 standard and the image analysis software. Table 3 shows the nodules characteristics of ductile irons.

Table 3. ADIs nodules characteristics

\begin{tabular}{c|c|c|c|c|c}
\hline & $\begin{array}{c}\text { Form } \\
\text { type }\end{array}$ & $\begin{array}{c}\text { Nodularity } \\
(\%)\end{array}$ & $\begin{array}{c}\text { Graphite } \\
\text { Area }(\%)\end{array}$ & $\begin{array}{c}\text { Nodule count } \\
\left(\text { nod. } / \mathrm{mm}^{2}\right)\end{array}$ & $\begin{array}{c}\text { Average nodule } \\
\text { diameter - AND } \\
(\mu \mathrm{m})\end{array}$ \\
\hline ADI 1 & $\mathrm{VI}$ & 99 & 13 & 196 & 29.1 \\
\hline ADI 2 & $\mathrm{VI}$ & 98 & 13 & 532 & 17.6 \\
\hline
\end{tabular}

In order to associate the mechanical properties with the fatigue tests results of contact materials, mechanical tests were made. Table 4 summarizes the results obtained with the mechanical tests.

Table 4. Mechanical properties of spur gears materials

\begin{tabular}{|c|c|c|c|c|c|c|}
\hline Material & $\begin{array}{c}\text { Tensile } \\
\text { Strength } \\
\text { (MPa) }\end{array}$ & $\begin{array}{c}\text { Elongation } \\
(\%)\end{array}$ & $\begin{array}{c}\text { Young's } \\
\text { Modulus } \\
\text { (GPa) }\end{array}$ & $\begin{array}{l}\text { Hardness } \\
\text { (HRc) }\end{array}$ & $\begin{array}{l}\text { Charpy } \\
\text { Energy } \\
\text { (Joules) }\end{array}$ & $\begin{array}{l}\text { Poisson's } \\
\text { Ratio }\end{array}$ \\
\hline AISI 8620 & $1250^{*}$ & $12.8^{*}$ & $205^{\star}$ & 58 & - & \multirow{2}{*}{$0.29^{*}$} \\
\hline AISI 4140 & $1965^{*}$ & $11.0^{*}$ & $205^{\star}$ & 56 & 4.5 & \\
\hline ADI 1 & 1546 & 2.1 & $183.8^{*}$ & 56 & - & \multirow{2}{*}{$0.25^{\star}$} \\
\hline ADI 2 & 1273 & 3.5 & 186.9 & 54 & 5.8 & \\
\hline
\end{tabular}

* Steels Information [9]

\subsection{Contact Fatigue Test}

For the contact fatigue tests, a FZG-LASC tribometer was used. Figure 2 shows an overview of this equipment. This tribometer was designed, manufactured and assembled in the Contact and Surface Laboratory (LASC-UTFPR). By using the power recirculation principle, two pairs of gears can be tested at the same time. The load is imposed on the gears by applying torque on the shaft where the wheel is mounted on (FZG loads $\mathrm{k} 6$ and $\mathrm{k} 9$ ). A twist on the wheel axis is achieved by applying an eccentric load, using a lever and dead weight.

\footnotetext{
* Technical contribution to the $2^{\text {nd }}$ International Brazilian Conference on Tribology - TriboBR 2014, November $3^{\text {rd }}$ to $5^{\text {th }}$, 2014, Foz do Iguaçu, PR, Brazil.
} 

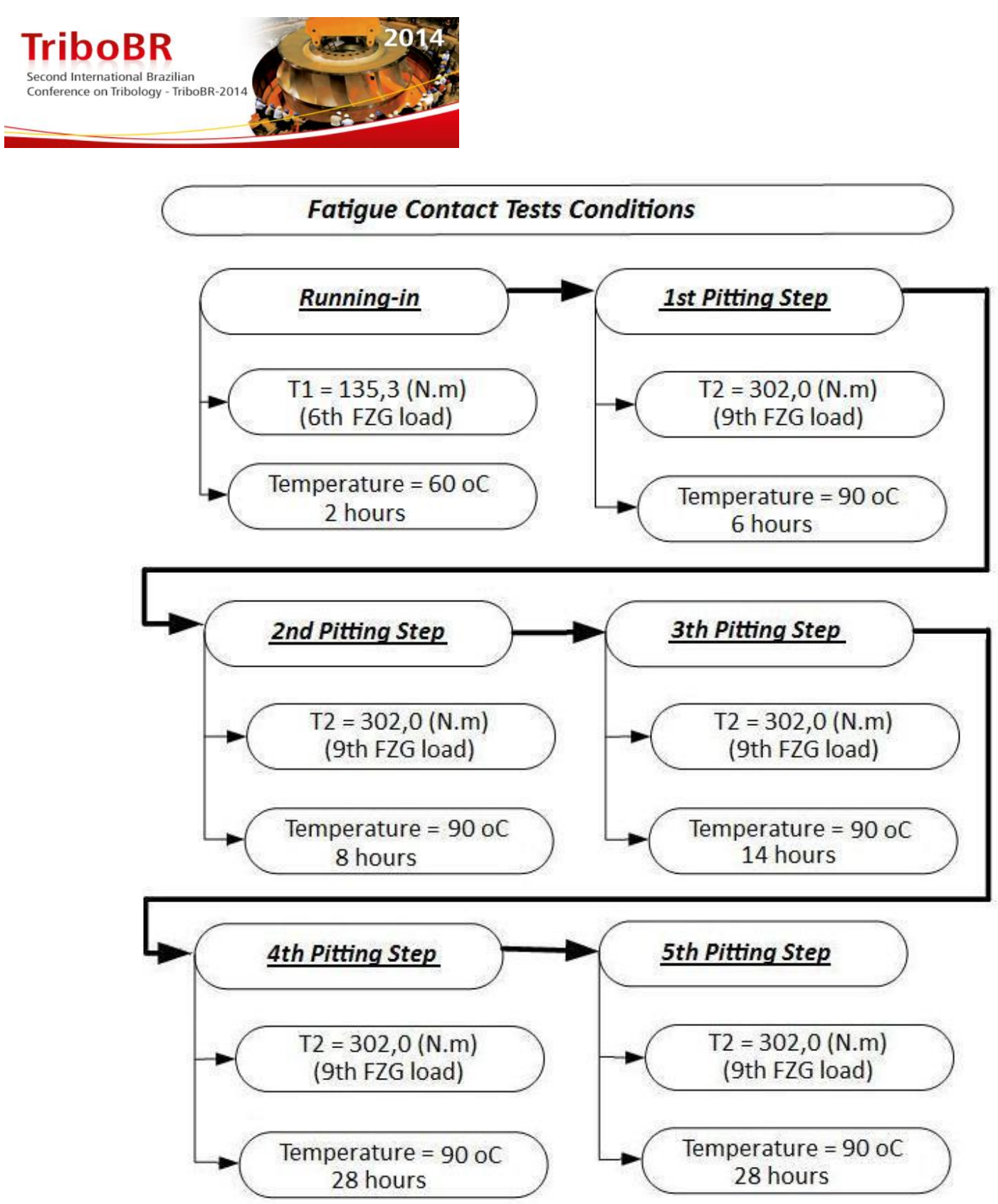

Figure 3. Operating conditions used in the contact fatigue tests.

To determine roughness of the gear teeth, measurements were made on the teeth flank in the axial direction (parallel to the gear axis). Five teeth of each pinion and wheel were selected randomly. The tooth schematic in Table 7 shows the directions of roughness measurements. The initial state of the tooth surfaces influences directly the fatigue contact life [10]. We can also notice that the initial gear finishing for all materials can be considered the same, so its roughness effect was neglected in the wear behavior study.

* Technical contribution to the $2^{\text {nd }}$ International Brazilian Conference on Tribology - TriboBR 2014, November $3^{\text {rd }}$ to $5^{\text {th }}$, 2014, Foz do Iguaçu, PR, Brazil. 


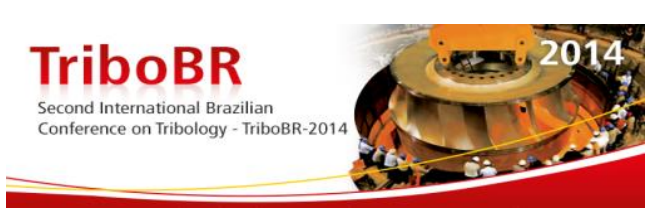

Table 7. Surface finish at the beginning of tests on the running-in stage.

\begin{tabular}{c|c|c|c}
\multicolumn{3}{|c}{} \\
\hline Materials & $\begin{array}{c}\mathrm{Ra} \\
(\mu \mathrm{m})\end{array}$ & $\begin{array}{c}\mathrm{Rsm} \\
(\mathrm{mm})\end{array}$ & $\begin{array}{c}\mathrm{Rvk} \\
(\mu \mathrm{m})\end{array}$ \\
\hline AISI 8620 & $0.9 \pm 0.1$ & $0.04 \pm 0.02$ & $1.0 \pm 0.2$ \\
\hline AISI 4140 & $1.0 \pm 0.4$ & $0.15 \pm 0.03$ & $1.7 \pm 1.0$ \\
\hline ADI 1 & $0.8 \pm 0.4$ & $0.05 \pm 0.03$ & $1.4 \pm 1.0$ \\
\hline ADI 2 & $1.0 \pm 0.1$ & $0.05 \pm 0.01$ & $1.5 \pm 0.4$ \\
\hline & & & adenddum \\
\hline
\end{tabular}

\subsection{Damaged by Pitting}

Macroscopic images were taken from the gear teeth flank, showing the condition before running-in and after each step of the fatigue tests, so that the damage evolution in the flanks with the loading cycles could be observed. These images were used to quantify the pitting area. This procedure was done for all damaged teeth of each gear.

Figure 4 (a) shows an image of a pinion tooth flank where it is possible to identify two regions: (1) the effective contact area and (2) the lateral areas where there is no contact during mesh. Areas with pitting damage identified in Figure 4 (b) are measured using image analyses software. The ratio of the damaged area and the effective contact area reports the percentage of damage on each tooth at each step of pitting test.

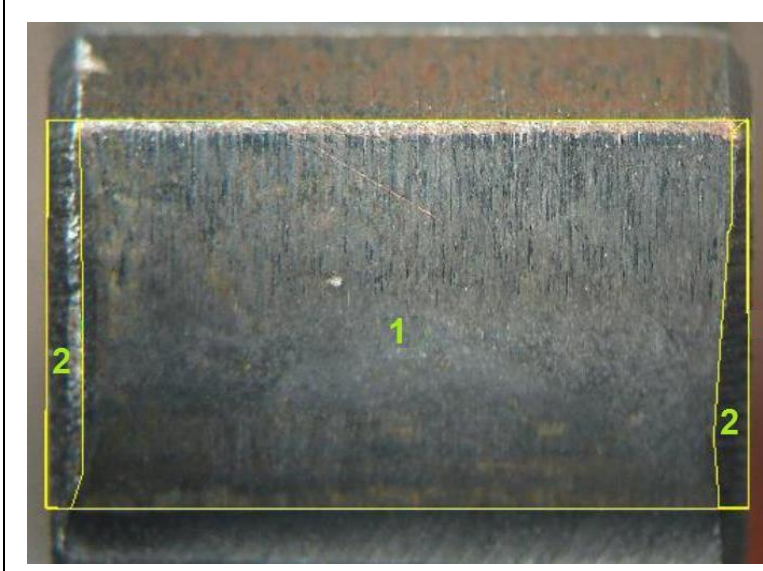

(a)

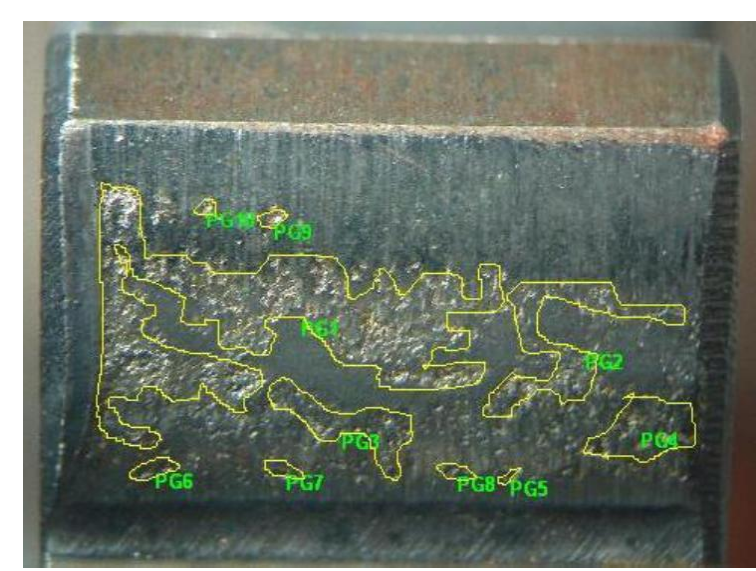

(b)

Figure 4. Images of AISI 8620 pinion tooth showing the surface aspect (a) before and (b) after pitting test.

The total damage of all the gear teeth was divided by the total active area of all flanks and, in this paper, the resulting value is called average damage area percentage $(A \%)$.

* Technical contribution to the $2^{\text {nd }}$ International Brazilian Conference on Tribology - TriboBR 2014, November $3^{\text {rd }}$ to $5^{\text {th }}$, 2014, Foz do Iguaçu, PR, Brazil. 
Finally, the Weibull statistical distribution was used to support wear results. This graphic, result of the statistical distribution of Weibull, relates the probability of failure of a component to the number of cycles that it will be submitted and it can be applied to the estimated periods of guarantee against failures made by mechanical equipment. For the study of fatigue, more precisely on the life time of a component, which is the most usual implementation of this tool, the Weibull distribution is simplified to a distribution of two parameters [11]. For the contact fatigue tests were developed charts for Weibull failure equivalent to $8 \%$ of pitting damage of active area of the teeth. Worn surfaces and subsurface were studied by using optical and scanning electron microscopes.

\subsection{Contact Stress}

To calculate the contact stress on the tooth flank, the analytical solution proposed by Hertz [12] was used. In this solution, the gear contact is analyzed as a contact between two cylinders, and it's assumed that their radii are equal to the tooth curvature radius in each point in contact. With these assumptions, the Hertzian semidimension $(a)$ is then found by Equation (1):

$$
a=\sqrt{\frac{4}{\pi} \cdot \frac{W}{b} \cdot \frac{R_{e q}^{\prime}}{E^{\prime}}}
$$

Where $\boldsymbol{W}$ is the normal load, $\boldsymbol{b}$ is the gear width, $\boldsymbol{R}^{\prime}{ }^{\prime}$ is the equivalent curvature radius (at the pitch point) and the effective Young modulus is $\boldsymbol{E}^{\prime}$. Listed below are the equations for each parameter.

$$
\begin{gathered}
E^{\prime}=\left(\frac{1-v_{1}^{2}}{E_{1}}+\frac{1-v_{2}^{2}}{E_{2}}\right)^{-1} \\
R_{e q}^{\prime}=\left(\frac{1}{R_{1}}+\frac{1}{R_{2}}\right)^{-1}
\end{gathered}
$$

A plot of the pressure distribution in the contact zone is depicted in Figure 5 . The contact pressure is maximum at the center $\left(\boldsymbol{p}_{\text {max }}\right)$ and zero at the edges of contact zone. The $p_{\text {máx }}$ can be obtained by Equation (4).

$$
p_{\text {máx }}=\frac{2 \cdot W}{\pi \cdot a \cdot b}
$$

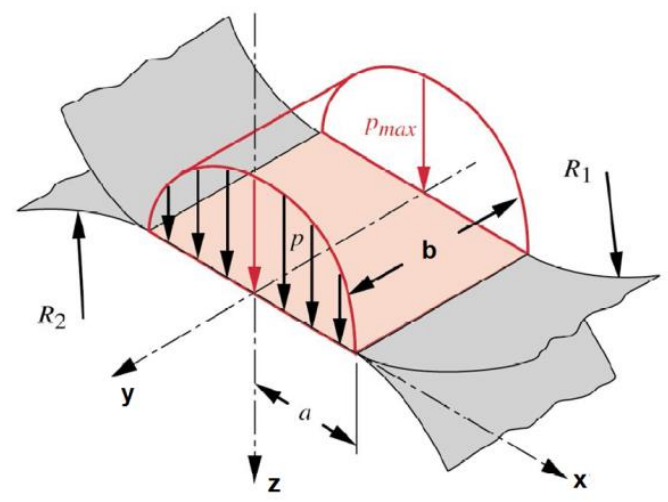

Figure 5. Ellipsoidal-prism pressure distribution and contact zones in cylindrical Hertzian contact [13].

According to the contact geometry shown in Figure 5, the maximum shear stress $(\tau 13)$ on the $\boldsymbol{z}$ axis that results from the combination of principal stresses (Equations 5) are:

* Technical contribution to the $2^{\text {nd }}$ International Brazilian Conference on Tribology - TriboBR 2014, November $3^{\text {rd }}$ to $5^{\text {th }}$, 2014, Foz do Iguaçu, PR, Brazil. 


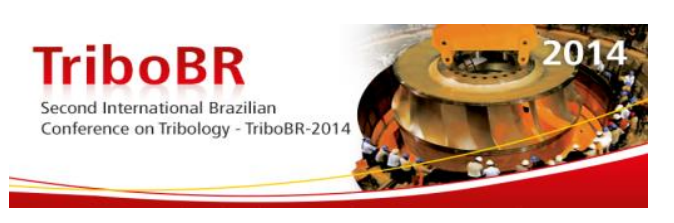

$$
\begin{aligned}
& \tau_{13}=\left|\frac{\sigma_{x}-\sigma_{z}}{2}\right|=\left|\frac{\sigma_{1}-\sigma_{3}}{2}\right|=\mid-\frac{p_{\text {máx }}}{a} \cdot\left[z-z^{2} \cdot\left(a^{2}+z^{2}\right)^{-\frac{1}{2}}\right] \\
& \tau_{13_{\text {MÀx }}}=\tau_{\text {máx }}=0.300 p_{\text {máx }} \quad(\text { for } \quad z=0.786 a)
\end{aligned}
$$

\subsection{Finite Element Modeling}

For better understanding of the stresses around the graphites and to estimate the concentration factor around it, a 3D finite element modeling was implemented using ANSYS Workbench ${ }^{T M}$ (11.0). In order to assure the involute curve, the teeth geometry was modeled using GearTeq ${ }^{\mathrm{TM}}$ (v. 2010), a software integrated with SolidWorks ${ }^{\circledR}$, and it was possible to align the point of contact in the pitch diameter and the action line with the $y$-axis for better and convenient results preview. It was decided to model only three teeth in each gear in the global simulation in order to avoid any distortions in the deformation field due to the stress concentration in the root of the contact tooth. Also, the inner diameter was modified to simplify the mesh.

A static analysis for ADI gears was done to recreate the stress field in the contact and around the nodules. Since the stresses fields require a higher mesh refinement to validate the results, it was used the submodeling tool in ANSYS Workbench. With that, it's possible to suppress details of the geometry in a macroscopic level (global analysis) using a coarse mesh and then re-insert them in the submodeling simulation. It's also possible to improve the mesh without increasing the simulation time by focusing only in the interest zone of the geometry [14]. In this case it's simulated the entire teeth, then it's zoomed a first time around the contact zone and finally it's zoomed a second time under the surface, with the insertion of de graphite nodules. In order to choose an appropriate geometry to the second submodeling, it's been simulated multiples graphite nodules at once and then compared to a single and isolated graphite nodule.

Experiments showed that the contact fatigue cracks nucleated between the contact and $200 \mu \mathrm{m}$ deep for the ADI gears teeth while in a hypothetical isotropic material with the same properties for the ADI had to nucleate cracks around $200 \mu \mathrm{m}$ deep, where the shear stress is maximum. That's why it was decided to analyze that region by varying a single nodule position in a second submodeling for different depths, starting near the contact and moving until the depth of $200 \mu \mathrm{m}$. These simulations were also compared to a group of nodules simulated at the same time to check which case showed higher shear stress and to know if a single graphite nodule stress field has influence in the adjacent nodule stress field, given the average distance between nodules. This way it's expected to understand how the position of each nodule influences in the stress concentration factor.

Other numerical analyses were made using the following boundary conditions and considerations:

- Contact modeled in the pitch diameter;

- Torque stage considered at 302 N.m, applied on the inner diameter face of the pinion (Table 6);

- Inner diameter face is fixed for the wheel and the $z$ dislocation is equal to zero for both side faces;

- Frictionless and non linear effects considered (Hertz contact) [12];

* Technical contribution to the $2^{\text {nd }}$ International Brazilian Conference on Tribology - TriboBR 2014, November $3^{\text {rd }}$ to $5^{\text {th }}$, 2014, Foz do Iguaçu, PR, Brazil. 


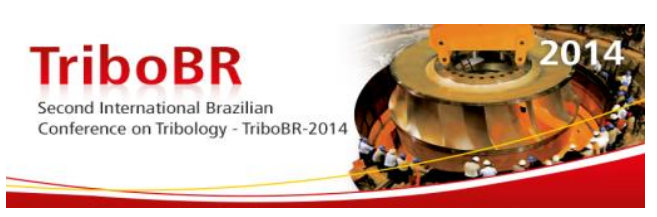

- To assure the contact and prevent that a gear tooth penetrate the other one it was used the Augmented Lagrange Formulation [14];

- Graphite nodules were modeled as a spherical shape since the ADls have almost $100 \%$ of nodularity (Table 3 );

- Validation simulations indicated that the highest stresses show up when the graphite is modeled as a void. So, even that it was reinforced that graphites cannot always be considered as voids [15], for engineering matters, this assumption helped to eliminate the numerical fluctuation into the results analysis and the physical explanation could be better explored;

- The percentage of nodular volume is also equal to the nodular area (Table 3);

- The first submodeling geometry is a $2.0 \times 2.0 \times 0.4 \mathrm{~mm}$ box that involves the contact zone in the symmetry plan;

- The second submodeling geometry is a $100 \times 100 \times 100 \mu \mathrm{m}$ box that translates between the surface and the depth of $200 \mu \mathrm{m}$ along the line action.

The refinement process is demonstrated in Figure 6 and Table 8 below, which represent the global and the submodeling meshes, the last ones implying in a notable refinement.

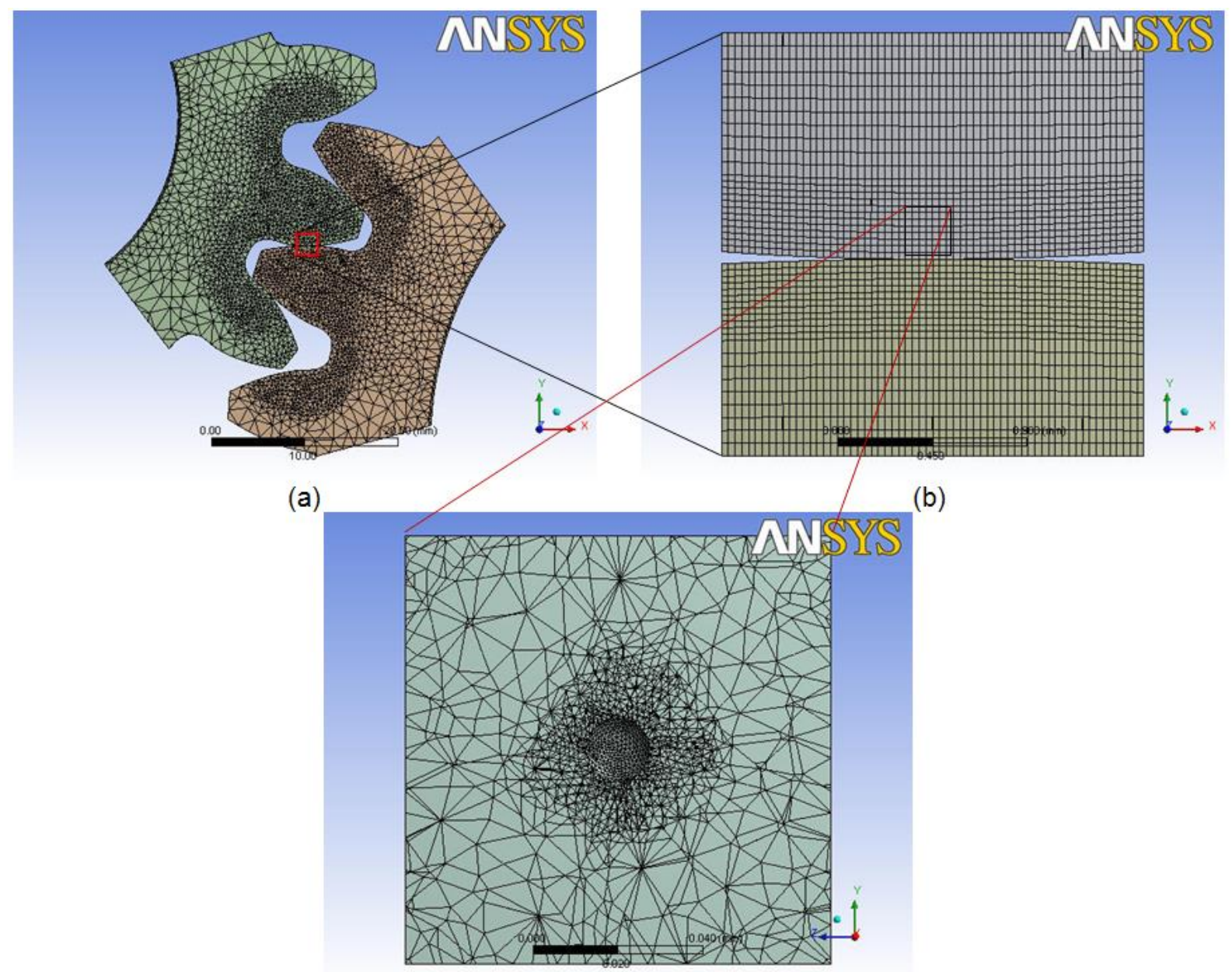

(c)

Figure 6. (a) Coarse mesh on global analysis (b) First submodeling - contact zone (c) Second submodeling - Nodule insertion.

* Technical contribution to the $2^{\text {nd }}$ International Brazilian Conference on Tribology - TriboBR 2014, November $3^{\text {rd }}$ to $5^{\text {th }}$, 2014, Foz do Iguaçu, PR, Brazil. 


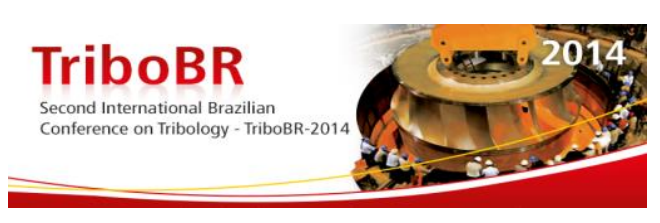

Table 8. Both ADI 1 and ADI 2 gears meshes

\begin{tabular}{c|c|c|c|c}
\cline { 2 - 5 } & Global Mesh & $\begin{array}{c}1^{\text {st }} \text { Submodeling } \\
\text { Mesh }\end{array}$ & $\begin{array}{c}2^{\text {nd }} \text { Submodeling } \\
\text { Mesh (ADI 1) }\end{array}$ & $\begin{array}{c}2^{\text {nd }} \text { Submodeling } \\
\text { Mesh (ADI 2) }\end{array}$ \\
\hline $\begin{array}{c}\text { Number of } \\
\text { nodes }\end{array}$ & 221,732 & 156,982 & $\sim 105,000$ & $\sim 62,000$ \\
\hline $\begin{array}{c}\text { Number of } \\
\text { elements }\end{array}$ & 140,291 & 35,464 & $\sim 42,300$ & $\sim 42,000$ \\
\hline
\end{tabular}

Finally, was defined a reference factor in order to understand how much the stresses can increase in the presence of the graphite nodules. This factor is defined as the numerical shear stress concentration factor (Ktns), which gives us the ratio between the maximum shear stress calculated in ANSYS for an ADI gear modeled as a nonisotropic material and an ordinary isotropic material with fixed maximum shear stress position (austempered matrix). This material was modeled with mechanical properties of ADIs (Table 4).

\section{RESULTS AND DISCUSSION}

\subsection{Wear Resistance}

The results of the total damage rate (average damage percentage / cycles number = $\mathrm{A} \% / \mathrm{N}$ ) for all the materials tested are shown in Figure 7. As might be expected, the AISI 8620 steel hardened, with higher surface hardness, has a greater wear resistance. However, the hardness of tested materials, despite having a very good correlation with pitting resistance is not the only characteristic able to explain the results shown bellow.

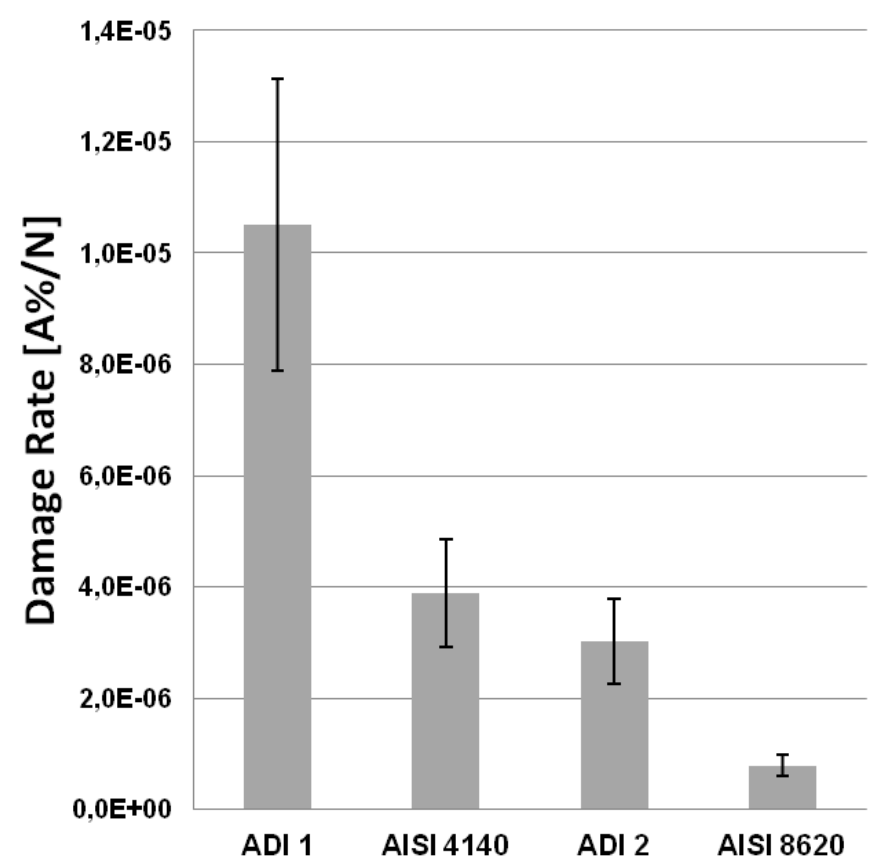

Figure 7. Damage rate for all materials tested.

Note that the ADI 2 shows similar values of damage resistance in relation to the induction hardened AISI 4140, which is a material traditionally used in gears. Table 4 shows that the absorbed energy in Charpy test is greater in ADI 2 that 4140, this result indicates that the ductile iron absorbs more energy at a fracture process. This

* Technical contribution to the $2^{\text {nd }}$ International Brazilian Conference on Tribology - TriboBR 2014, November $3^{\text {rd }}$ to $5^{\text {th }}$, 2014, Foz do Iguaçu, PR, Brazil. 


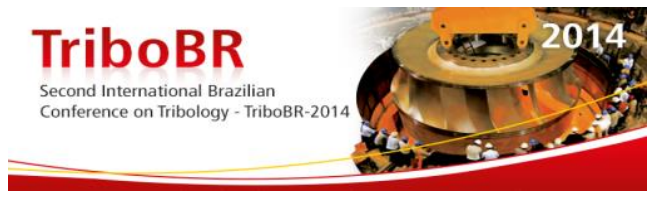

ability to retain the propagation of a crack is more related to the fracture toughness, which generally has higher values o ADI grade 3 [4].

Figure 8 presents the failure probability in relation of load cycles (Weibull chart) for all types of materials used in the manufacture of gears. This Weibull curve, the end of life has been standardized as $8 \%$ of the effective flanks area of the teeth with pitting damage. Table 9 shows the Weibull parameters $(\eta$ : life characteristic and $\beta$ : slope) for the four materials tested.

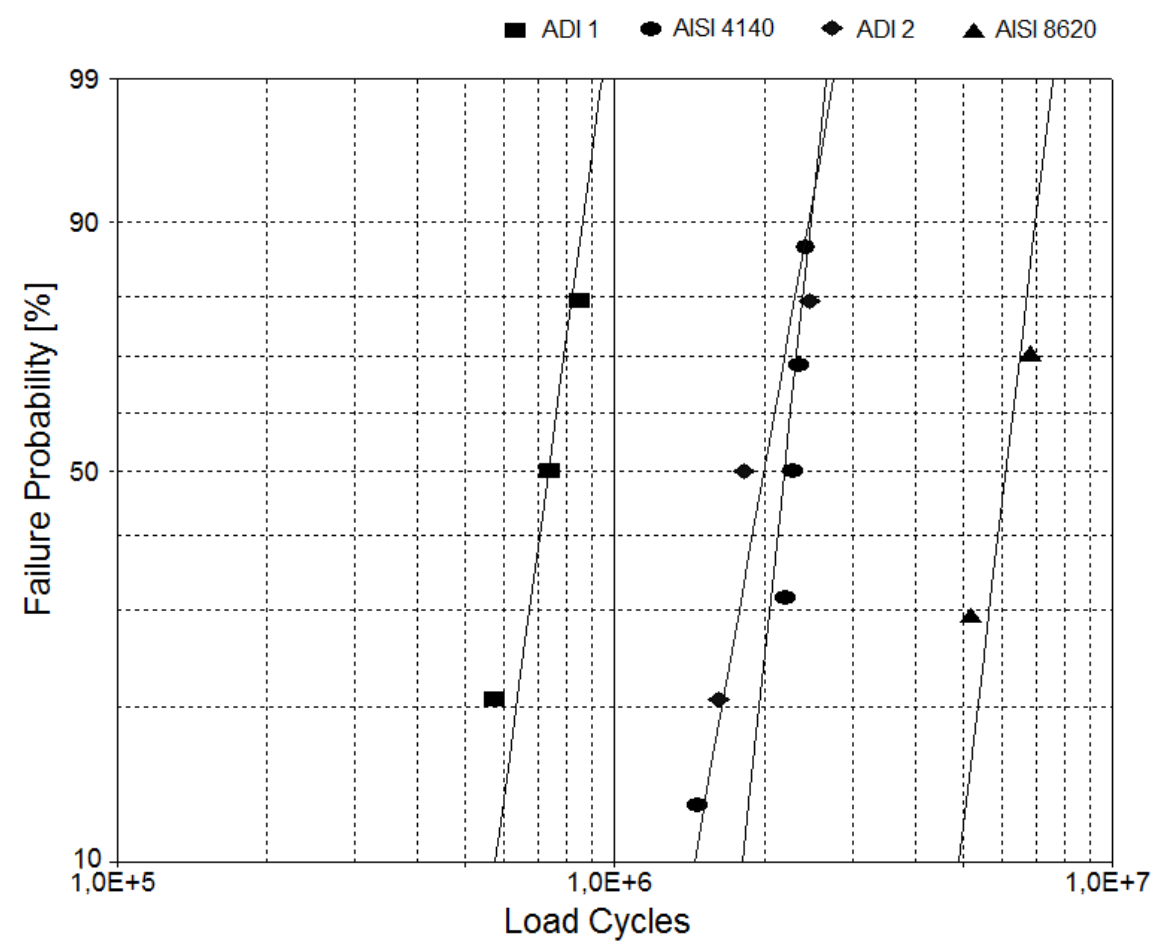

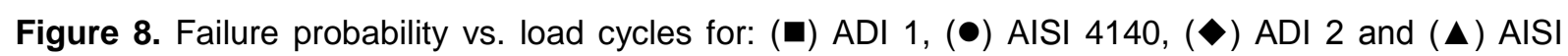
8620.

Once again it is observed, in Figure 8 and Table 9, that the behavior of pitting resistance is very similar between the ADI 2 and AISI 4140. Their mean lifetime $(\eta)$ are near to 2.2 millions of cycles. These results show that despite presenting a lower mechanical resistance and having a natural concentrator stress in its microstructure, an ADI with a high stiffness matrix and an appropriate nodule size can present high pitting resistance, so it can compete with traditional materials in the gear teeth manufacturing like the AISI 4140 induction hardening.

Table 9 - Weibull parameters for all materials tested.

\begin{tabular}{c|c|c}
\hline Material & $\begin{array}{c}\beta \\
\text { (Slope) }\end{array}$ & $\begin{array}{c}\eta \\
\text { (Medium life) }\end{array}$ \\
\hline ADI1 & 7.65 & $0.77 \times 10^{6}$ \\
\hline ADI 2 & 5.84 & $2.12 \times 10^{6}$ \\
\hline AISI 4140 & 9.82 & $2.27 \times 10^{6}$ \\
\hline AISI 8620 & 8.72 & $6.35 \times 10^{6}$ \\
\hline
\end{tabular}

* Technical contribution to the $2^{\text {nd }}$ International Brazilian Conference on Tribology - TriboBR 2014, November $3^{\text {rd }}$ to $5^{\text {th }}$, 2014, Foz do Iguaçu, PR, Brazil. 


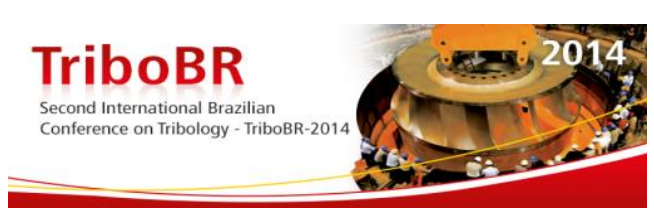

\subsection{Austempered Ductile Iron Behaviour: ADI 1 versus AD 2}

\subsubsection{Cracks analysis}

Figures 7 and 8 clearly show that with the same chemical composition and heat treatment conditions, the ADI 2 is more suited to the gear application than the ADI 1 . Table 4 shows that the ADI 1 is a more rigid material, but with a reduced ability of strain before rupture.

However, the main difference between these materials is related to the size of graphite nodules. Figure 9 presents the ADI 1 and ADI 2 micrographs taken close to the surface of teeth flank. Smaller size nodules (ADI 2) lead to a higher local stress concentration factor and to a formation of cracks from the nodes in shorter times. However, for the formation of pitting craters, beyond the period of cracks nucleation, the propagation stage is also very important.

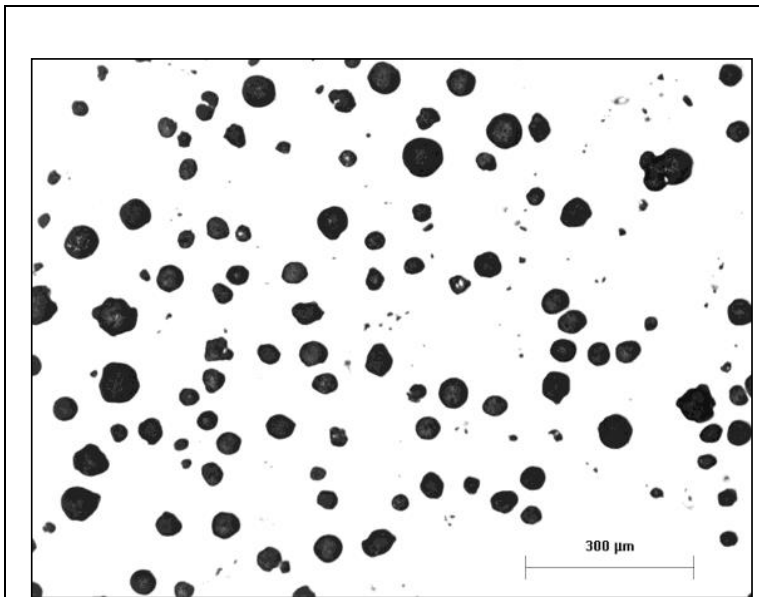

(a)

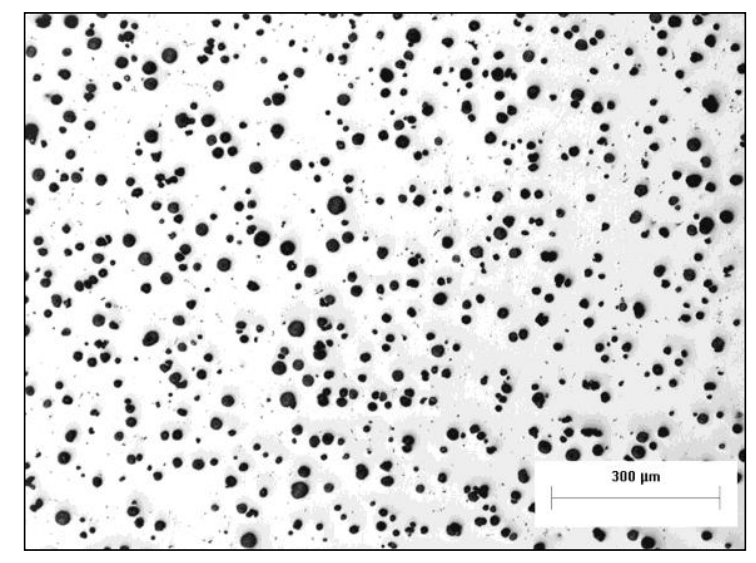

(b)

Figure 9. Light microscopy, unetched. Size, shape, and distribution of graphite nodules in (a) ADI 1 196 (nod. $/ \mathrm{mm}^{2}$ ) and (b) ADI $2-532$ (nod. $/ \mathrm{mm}^{2}$ ).

Figure 10 shows the form of cracks in the region of the gear pitch diameter tested for both austempered ductile irons. Note that in the ADI 2 there is a greater amount of cracks, with branches and also cracks connected between the nodules, both spreading toward the surface and into the tooth. Analyzing the ADI 1, the cracks present less branching ability and tend to grow toward the tooth surface. This fact can provoke a higher material release (spalls) and accelerate the wear process.

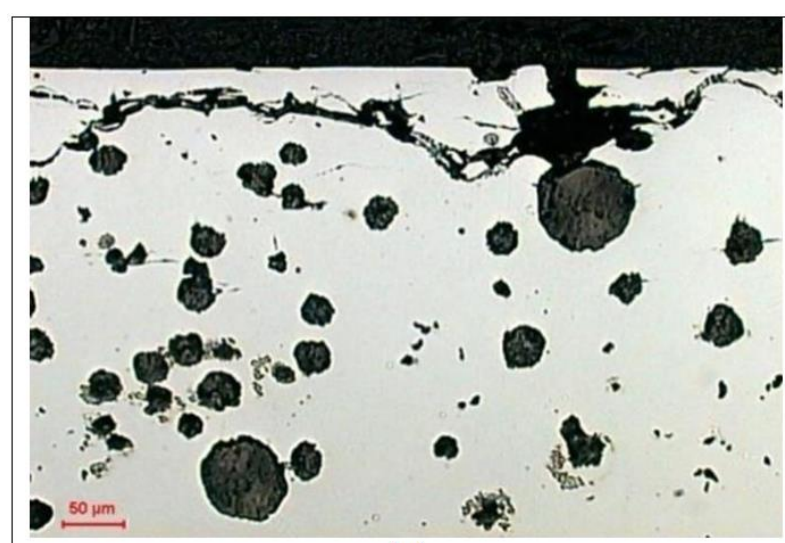

(a)

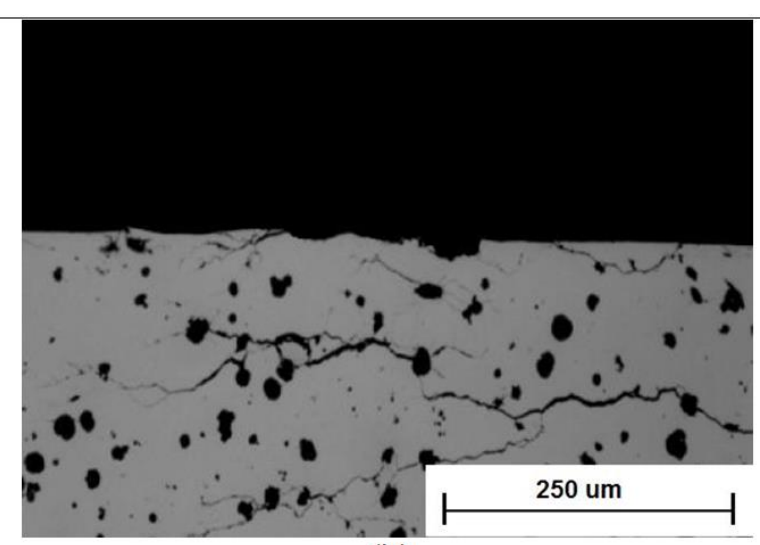

(b)

Figure 10. Photomicrograph of gear in diametric pitch region shows crack in surface and sub-surface. (a) ADI 1 and (b) ADI 2.

* Technical contribution to the $2^{\text {nd }}$ International Brazilian Conference on Tribology - TriboBR 2014, November $3^{\text {rd }}$ to $5^{\text {th }}$, 2014, Foz do Iguaçu, PR, Brazil. 


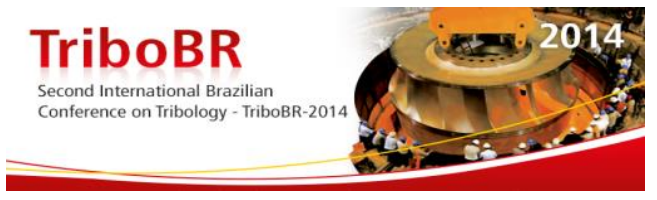

The presence of graphite nodules provides antagonist effects over the crack nucleation and growth steps. The graphites induce a stress concentration in the evolving matrix, which makes it easier to nucleate cracks. Although, when a crack grows, it may reach a graphite nodule, that increases the tip radius substantially, and this reduces its growth rate. The pitting generation in gears seems to be controlled by the crack development, so that, the ADI with higher amount of graphites presented lower pitting generation rate.

Greno [4] explains that in ADI with higher amounts of nodules, the higher is the occurrence of a crack propagation mechanism referred to as "apparent crack branching mechanism". The higher branch occurrence in ADI 2 led to a greater resistance to pitting formation.

In impact test (Figure 11a) the ADI fracture occurs due to mix of mechanisms: dimples generation near the graphite nodules and a quasi cleavage in the austempered matrix. This is especially true in ADI austempered under $320^{\circ} \mathrm{C}$. In the teeth surface, the pitting is generated due to a subsurface fatigue (crack propagation mode II), which is mainly a fragile crack growth process, with an extreme low plastic deformation associated to the fracture process. The images in Figure 11 illustrate all this, exemplified for the ADI 2.

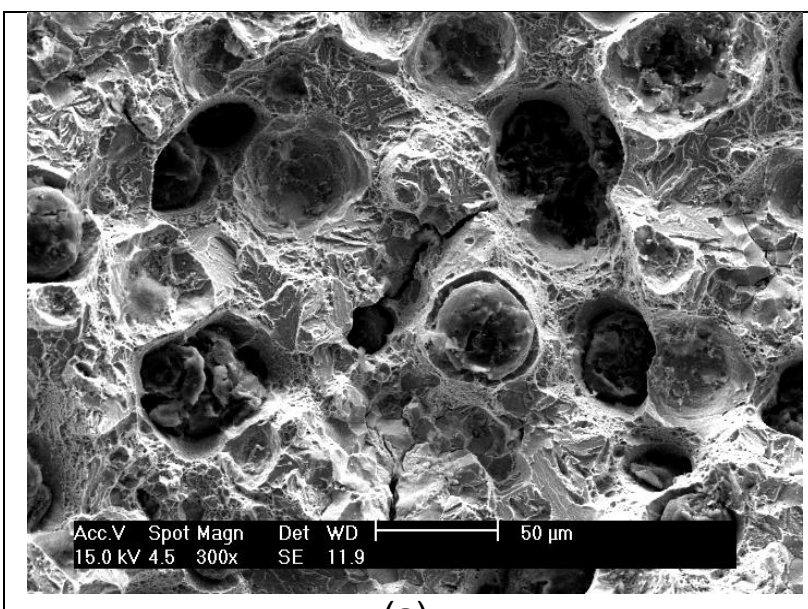

(a)

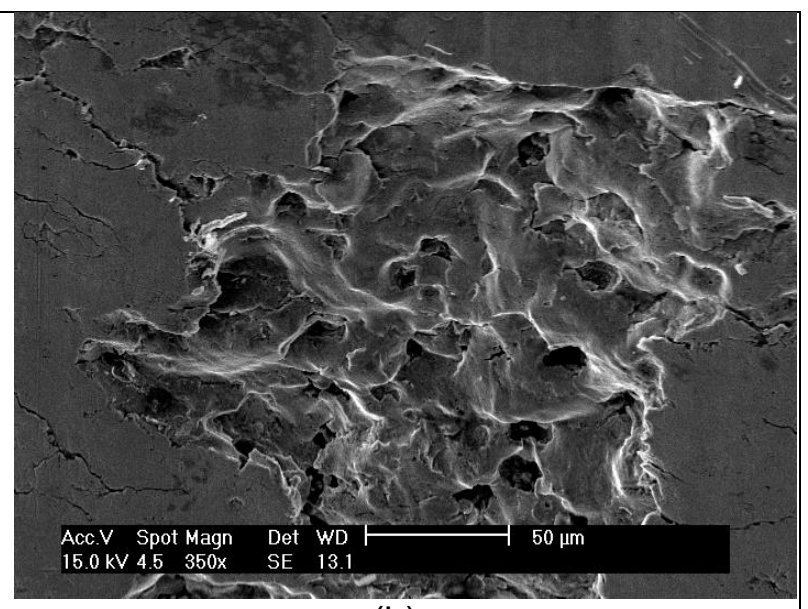

(b)

Figure 11. SEM photomicrographs of ADI 2 material: (a) fracture surface in impact test, (b) surface of tooth with pitting damage after FZG tests.

Some cracks nucleated in the surface and spread toward the interior of the teeth. However, given the fact that the surfaces finishing in the teeth are identical and that no casting defect was detected in the analyzed teeth, there wasn't a trend to higher crack nucleation in the surface when comparing both ADIs. Although, the a/AND ratio (Hertzian semi-dimension / average nodule diameter) is relevant to understand the stress severity in the contact region. Dommarco et al. [3] in ADIs contact fatigue tests with three different sizes of nodules also found less pitting resistance for larger nodules. However, in this work the authors correlate the nodules size with the contact area size, showing that the stress state in contacts with smaller nodules is less severe. Table 10 shows a similar study with Dommarco et al. [3] where the a/AND ratio is also proportional to the contact fatigue life.

Table 10. Hertzian semi-dimension / Average Nodule Diameter (a/AND)" ratios for ADIs

\begin{tabular}{|c|c|c|c|}
\hline Material & $a(\mu \mathrm{m})$ & AND $(\mu \mathrm{m})$ & $a /$ AND \\
\hline ADI 1 & 264.7 & 29.1 & 9.1 \\
\hline ADI 2 & 262.5 & 17.6 & 15.0 \\
\hline
\end{tabular}

\footnotetext{
* Technical contribution to the $2^{\text {nd }}$ International Brazilian Conference on Tribology - TriboBR 2014, November $3^{\text {rd }}$ to $5^{\text {th }}$, 2014, Foz do Iguaçu, PR, Brazil.
} 


\subsubsection{Finite Element Analysis}

First the mesh and the boundary conditions were validated by comparing the normal load in a global analysis. After submodeling the contact area, the contact pressure $\left(p_{\text {máx }}\right)$ and the Hertzian semi-dimension $(a)$ could converge as it's shown in Table 11.

Table 11. Numerical mesh validation

\begin{tabular}{|c|c|c|c|c|c|}
\hline & \multirow{3}{*}{$\begin{array}{c}\text { Analytical } \\
8927.2\end{array}$} & \multirow{3}{*}{$\begin{array}{c}\text { Numerical } \\
8928.7\end{array}$} & \multirow{3}{*}{$\begin{array}{c}\text { Error (\%) } \\
0.02\end{array}$} \\
\hline & & & & & \\
\hline$\overline{\mathbb{D}}$ & Normal Force - $W$ & ADI 1 & & & \\
\hline$\frac{0}{0}$ & $(\mathrm{~N})$ & ADI 2 & 8927.2 & 8928.6 & 0.02 \\
\hline \multirow{8}{*}{ 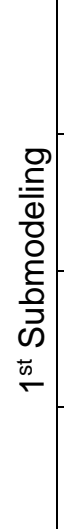 } & \multirow{2}{*}{$\begin{array}{l}\text { Maximum Contact Pressure }-p_{\text {máx }} \\
(\mathrm{MPa})\end{array}$} & ADI 1 & 1533.4 & 1522.6 & 0.7 \\
\hline & & ADI 2 & 1546.3 & 1533.7 & 0.8 \\
\hline & \multirow{2}{*}{$\begin{array}{l}\text { Hertzian semi-dimension }-a \\
\qquad(\mu \mathrm{m})\end{array}$} & ADI 1 & 264.7 & 265.9 & 0.5 \\
\hline & & ADI 2 & 262.5 & 263.5 & 0.4 \\
\hline & \multirow{2}{*}{$\begin{array}{l}\text { Maximum Shear Stress }-\tau_{\text {máx }} \\
(\mathrm{MPa})\end{array}$} & ADI 1 & 460.0 & 493.9 & 7.4 \\
\hline & & ADI 2 & 463.9 & 494.3 & 7.2 \\
\hline & \multirow{2}{*}{$\begin{array}{l}\text { Distance from contact }-z \\
(\mu \mathrm{m})\end{array}$} & ADI 1 & 208,1 & 216.9 & 4.2 \\
\hline & & ADI 2 & 206.3 & 217.4 & 5.4 \\
\hline
\end{tabular}

According to these results, the normal force, the maximum contact pressure and the Hertzian semi-dimension had an excellent agreement, with errors smaller than $1 \%$, which validated the numerical model with analytical one that considers two cylinders in contact. Although, since the real geometry represents an involute curve in the contact, the maximum shear stress values and the distance $z$ didn't had such agreement, as expected, deviating from the analytical solution between 4.2 and $7.4 \%$. So, we can say that the Hertz related parameters (as W, $p_{\text {máx }}$ and $a$ ) had an excellent approach since they are directly related with the surface's reactions. Moreover, since the subsurface variables ( $\tau_{\max }$ and $z$ ) are dependent on those ones, the errors spread to the subsurface because of the geometry. The numerical solution showed that the maximum shear stress point actually occurs a little bit deeper than the analytical solution and its error follow the range of the maximum shear stress error. The little difference between the ADI 1 and ADI 2 Young modulus explains why these results are so close.

The shear stress field in ADI 1 can be visualized in Figure 12 (a) and (b). It reinforces the fact that the maximum shear stress point occurs under de surface [12] and the scale bar also shows the solution convergence after the submodeling process. The same is shown with the contact pressure in Figure 12 (c) and (d), where the nonstructured mesh for the global analysis evolved to a regular one, so the pressure distribution got more homogeneous and could be compared with the analytical value.

\footnotetext{
* Technical contribution to the $2^{\text {nd }}$ International Brazilian Conference on Tribology - TriboBR 2014, November $3^{\text {rd }}$ to $5^{\text {th }}$, 2014, Foz do Iguaçu, PR, Brazil.
} 


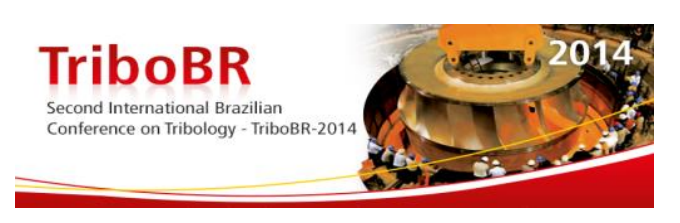

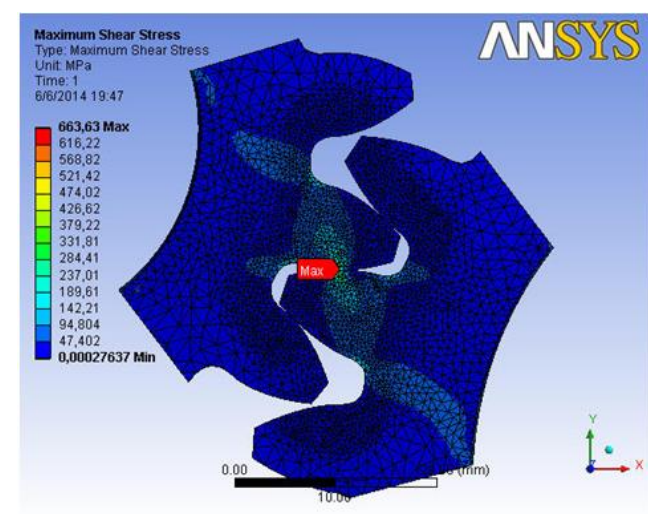

(a)

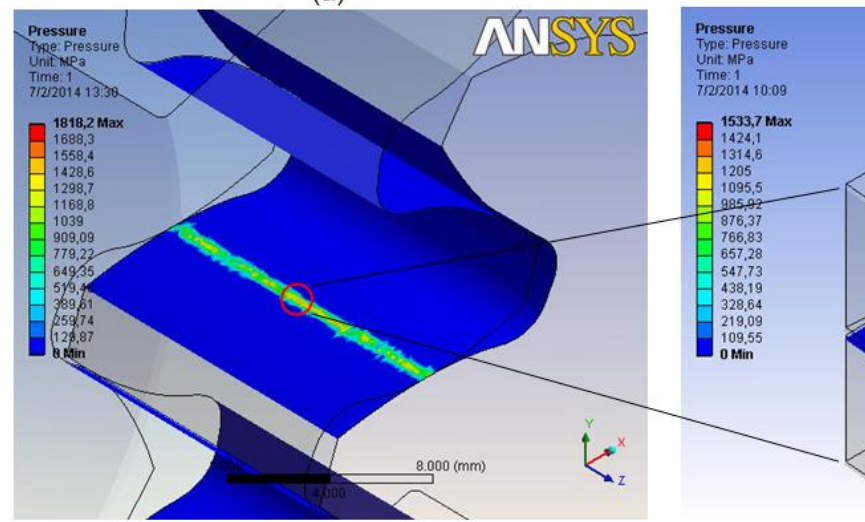

(c)

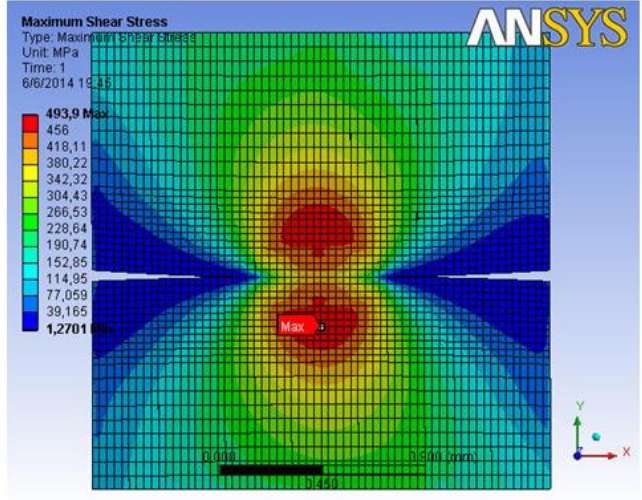

(b)

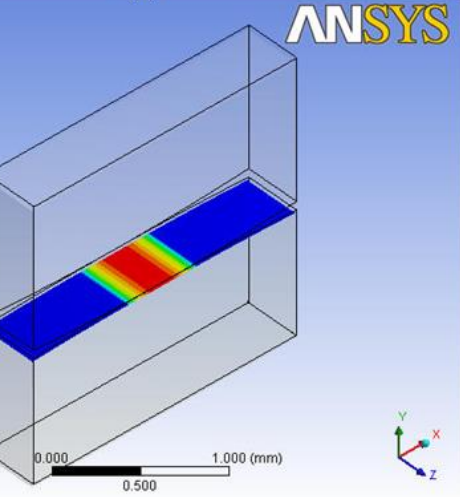

(d)

Figure 12. (a) ADI 1 shear stress field in a coarse and inaccurate mesh (global analysis). (b) Mesh from (a) after the $1^{\text {st }}$ submodeling. (c) Contact pressure on ADI 2 (global analysis). (d) Contact after the $1^{\text {st }}$ submodeling.

Then, in the second submodeling it was possible to estimate the numerical stress concentration factor due to the presence of graphite nodules. First, it was discovered that multiple nodules simulated at the same time showed a lower maximum shear stress around each nodule compared to the isolated nodule simulations. That was observed for both ADIs and Figure 13 shows the ADI 2 simulations. The distance between the graphite nodules in Figure 13 (a) is $40 \mu \mathrm{m}$, respecting the area distribution, and the distance from the inferior nodule center to the contact is around $20 \mu \mathrm{m}$.

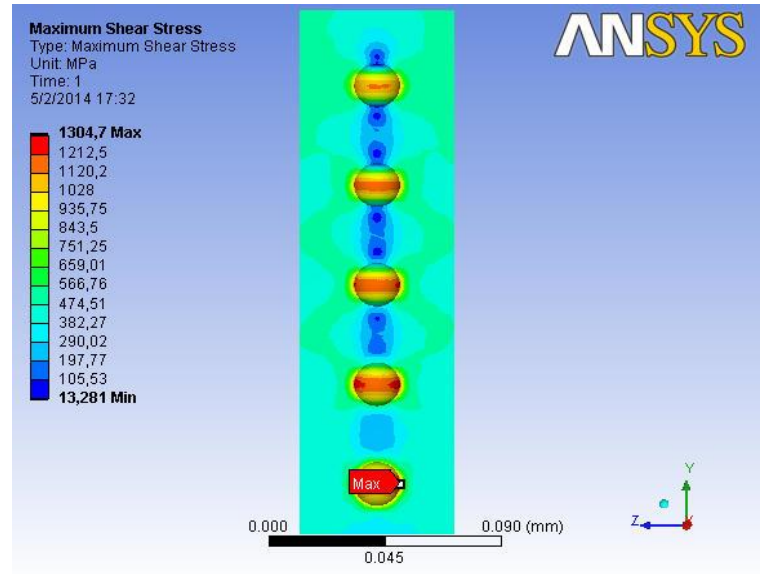

(a)

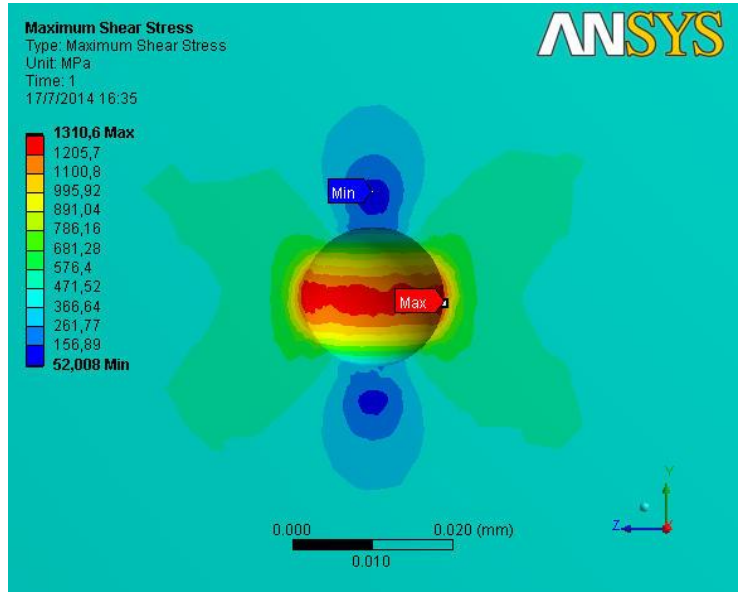

(b)

Figure 13. (a) Shear stress field around multiples nodules simulation in ADI 2. (b) Shear stress field around an isolated ADI 2 nodule simulation at $100 \mu \mathrm{m}$ distance from the contact.

* Technical contribution to the $2^{\text {nd }}$ International Brazilian Conference on Tribology - TriboBR 2014, November $3^{\text {rd }}$ to $5^{\text {th }}, 2014$, Foz do Iguaçu, PR, Brazil. 
For this level of distribution and spacing between nodules, the stress fields from each graphite nodule indicate they relax the adjacent stress field, relaxing the overall stress state. Considering the worst case for engineering purposes, that's why the remaining simulations only take account single and isolated nodules. That consideration is valid for every distance between the contact and $200 \mu \mathrm{m}$, which is proven in Figure 14.

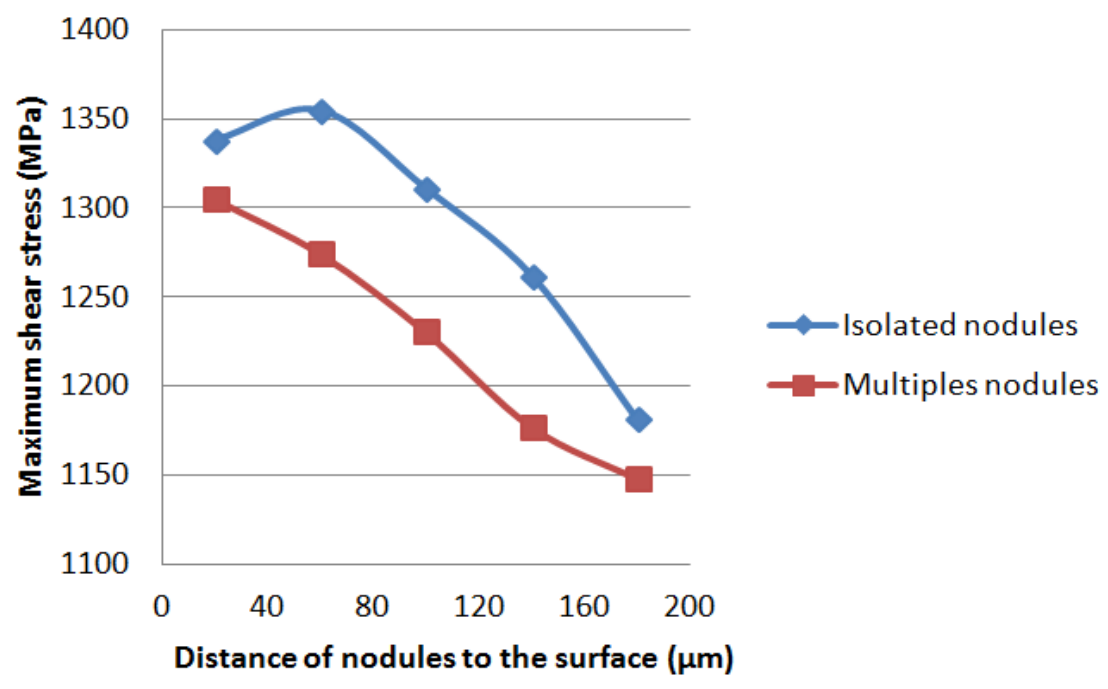

Figure 14. ADI 2 maximum shear stress at each location.

Thus, considering only simulations with single nodules at once it was possible to calculate for both ADIs the numerical stress concentration factor. Ktns was calculated at each nodule position varying between the contact and $200 \mu \mathrm{m}$ for every $20 \mu \mathrm{m}$ as shown in Figure 15.

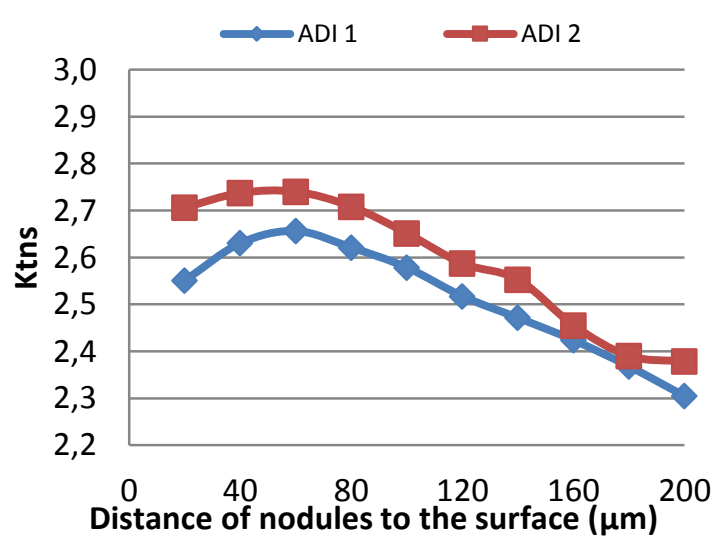

Figure 15. ADI 1 and ADI 2 numerical shear stress concentration factors (Ktns).

Figure 15 shows that the Ktns had its maximum around $60 \mu \mathrm{m}$ and it is higher for ADI 2, as expected. Because the ADI 2 average nodule diameter is smaller than the ADI 1 that provides a more severe stress field. However, the ADI 2 medium life is higher than the ADI 1 (Table 9) which indicates that the stress concentration factor is not the main variable to examine the gears lives. At the same time, given a similar graphite distribution (graphite area), the higher amount of graphite, the higher the gear's life.

* Technical contribution to the $2^{\text {nd }}$ International Brazilian Conference on Tribology - TriboBR 2014, November $3^{\text {rd }}$ to $5^{\text {th }}$, 2014, Foz do Iguaçu, PR, Brazil. 


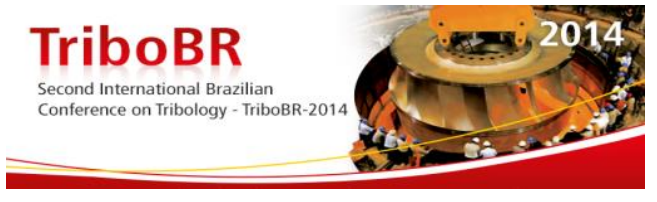

\section{CONCLUSION}

In contact fatigue tests with severe load, the carburized AISI 8620 steel proved more adequate than the austempered ductile iron, showing that the mechanical properties are critical in the resistance to damage in gear contact.

The austempered ductile iron with small nodule size showed to be very competitive with wear resistance similar to AISI 4140 steel induction hardened.

The use of the submodeling tool in the finite element method showed to be very good to study contact stress since we could easily validate the results with the analytical values. The results from submodeling showed that the nodules indicate the presence of a concentration stress, but their size doesn't affect the contact fatigue life as much as the total amount of nodules, which is independent of the ductile iron microstructure. The size and number of nodules affects both the nucleation and the propagation stage of cracks. And ADIs with higher amount of nodules have a greater wear resistance.

Also, compared to the Hertz contact theory (isotropic material), the presence of graphite nodules indicates a non-isotropic material and made the maximum shear stress point moves toward the surface. Given the graphite morphology, the maximum numerical shear stress concentration factor (Ktns) was around 2.65 for ADI 1 and 2.75 for ADI 2, near to $60 \mu \mathrm{m}$ from the surface.

Observations during the simulation phase showed that the Ktns factor may be overestimated around 0.3 because the graphites were modeled as voids and due to the numerical fluctuations. This makes the previously values fall to 2.35 for ADI 1 and to 2.45 for ADI 2.

\section{Acknowledgments}

The authors would like to express their sincere gratitude to the support from National Scientific and Technological Development Council (CNPq Project 134251/2007-5), the Brazilian funding PIBIC scholarship in the program PAE-REUNI and the companies: Wieser \& Pichler Cia. Ltda and TUPY S.A.

\section{REFERENCES}

1 Blackmore PA, Harding RA. Journal of Heat Treating. 1984; V.3, No 4: 310-325.

2 Aranzabal J, Serramoglia G, Goria CA, Rousière D. Development of a mixed (ferriticausferritic) ductile iron for automotive suspension parts. International Journal of Cast Metals Research. 2003. Vol. 16, no1-3: 185-190, 2003.

3 Dommarco RC, Jaureguiberry AJ, Sikora JA. Rolling contact fatigue resistance of ductile iron with different nodule counts and matrix microstructures. Wear. 2006; 261: 172-179.

4 Greno GL, Otegui JL, Boeri RE. Mechanisms of fatigue crack growth in ADI. International Journal of Fatigue. 1999; 21: 35-43.

5 Kobayashi T. Strength and Toughness of Materials. Tokyo: Springer; 2004.

6 Harding RA. Austempered Ductile Irons-Gears. Material and Design. 1984; Vol. 6, n־4: 177-184.

7 Martins R, Seabra J, Magalhães L. Austempered ductile iron (ADI) gears: power loss, pitting and micropitting. Wear. 2008; 264, 838-849.

8 Magalhães L, Martins R, Seabra J. Low-loss austempered ductile iron gears: Experimental evaluation comparing materials and lubricants. Tribology Internacional, $2011 ; 46,97-105$.

9 Matweb; 2014. Available at: www.matweb.com.

\footnotetext{
* Technical contribution to the $2^{\text {nd }}$ International Brazilian Conference on Tribology - TriboBR 2014, November $3^{\text {rd }}$ to $5^{\text {th }}$, 2014, Foz do Iguaçu, PR, Brazil.
} 
10 Muraro MA, Reisdorfer JU, Koda F, Silva CH. The influence of contact stress distribution and specific film thickness on the wear of spur gears during pitting tests. J. Brazilian Society of Mechanical Sciences and Engineering, 2012; 34: 135-144.

11 Lipson C, Sheth NJ. Statistical Design and Analysis of Engineering Experiments. McGraw-Hill: pp. 36-44; 1973.

12 Johnson KL. Contact mechanics. Cambridge: Cambridge University Press, p. 84-106; 1987.

13 Norton RL. Projeto de Máquinas: Uma Abordagem Integrada. $4^{\text {nd }}$ Ed., Bookman; 2010.

14 ANSYS Workbench. Version 11.0. USA, 2010.

15 Hervas I, Bettaieb MB, Thuault A, Hug E. Graphite nodule morphology as an indicator of the local complex strain state in ductile cast iron. Materials and Design. 2013; 52: 524532.

16 Brunetti C, Leite MV, Pintaúde G. Effect of specimen preparation on contact fatigue wear resistance of austempered ductile cast iron. Wear. 2007; Vol. 263, Issues 1-6: 663-668.

17 Costa N, Machado N, Silva FS. Influence of graphite nodules on fatigue limit of nodular cast iron. Ciência e Tecnologia dos Materiais. 2008; Vol. 20, no 1-2: 120-127.

18 Guesser WL, Franco E, Lussoli C, Costa CE. Ferro nodular austemperado a partir da zona crítica. 14 Congresso de Fundição ABIFA. São Paulo; 2009.

19 Guesser WL. Propriedades Mecânicas dos Ferros Fundidos. São Paulo: Blucher; 2009.

* Technical contribution to the $2^{\text {nd }}$ International Brazilian Conference on Tribology - TriboBR 2014, November $3^{\text {rd }}$ to $5^{\text {th }}$, 2014, Foz do Iguaçu, PR, Brazil. 